ELECTRONIC LETTER

\title{
Robust fragile X (CGG) genotype classification using a methylation specific triple PCR assay
}

\author{
Y Zhou, H-Y Law, C D Boehm, C-S Yoon, G R Cutting, I S L Ng, S S Chong
}

J Med Genet 2004;41:e45 (http://www.jmedgenet.com/cgi/content/full/41/4/e45). doi: 10.1136/jmg.2003.012716

$\mathrm{F}$ ragile $\mathrm{X}$ syndrome (MIM No 3009550) is the most common inherited mental retardation disorder, affecting approximately $\mathrm{l}$ in 4000 males and 1 in 8000 females. ${ }^{1}$ Its name was derived from the observation of a fragile site on chromosome Xq27.3, designated FRAXA (fragile site, X chromosome, A site). This syndrome is caused by mutations in the fragile $X$ mental retardation- 1 gene (FMRI), more than $95 \%$ of which involve hyperexpansion and hypermethylation of a polymorphic CGG trinucleotide repeat in the $5^{\prime}$ untranslated region ( $5^{\prime}$ UTR) of the gene. ${ }^{1-4}$

Among normal individuals, the number of CGG repeats ranges between 6 and 55. In most affected patients, the CGG repeats are massively expanded to over 200 repeats, and the gene becomes methylated at CpG islands and is silenced. Individuals with CGG repeats in the premutation range of 55 to 200 repeats are clinically unaffected, but these repeats are likely to be unstable during transmission to the next generation. ${ }^{12}$ This instability depends on the size of the premutation allele and is much more pronounced during maternal transmission. The larger the premutation alleles, the more likely they will be to expand to full mutations. ${ }^{156}$

Numerous diagnostic methods have been developed for fragile $\mathrm{X}$ syndrome, including cytogenetic, Southern blot, polymerase chain reaction (PCR), methylation specific PCR (ms-PCR), reverse transcription PCR (RT-PCR), and immunohistochemical analyses. ${ }^{7-10}$ The most commonly used molecular methods for the diagnosis of fragile $\mathrm{X}$ syndrome are Southern blot and PCR/ms-PCR analyses. The major disadvantage of the Southern blot method is its difficulty in distinguishing between large normal and small premutation alleles, while current PCR/ms-PCR techniques have poor sensitivity for detecting large premutation and full mutation alleles, especially in females. ${ }^{7-10}$ Although the combination of Southern and PCR methods enables reliable diagnosis of fragile $\mathrm{X}$ syndrome, the whole procedure is tedious and time consuming.

We have developed an alternative molecular diagnostic test for fragile $\mathrm{X}$ syndrome based on methylation specific PCR which reliably discriminates between normal, premutation, and full mutation affected males and females. After sodium bisulphite treatment, one specific PCR reaction detects all non-methylated allele sizes (normal and premutation), while two PCR reactions are used to classify the methylated allele(s) (normal, premutation, and full mutation). Using this triple ms-PCR strategy, we accurately classified the fragile $X$ status in all 44 male and 45 female DNA samples that were tested.

\section{METHODS}

DNA samples

Initial assay optimisation was undertaken on the following eight lymphoblastoid cell lines: GM07175 (normal female with 30 and 23 CGG repeat alleles), GM06907 (premutation female with 95-140 and 23 CGG repeat alleles), GM06896 (premutation female with 85 and 29 CGG repeat alleles), GM07537 (full mutation female with >200 and 29 CGG

\section{Key points}

- A rapid and reliable methylation specific polymerase chain reaction (PCR) system is described for the molecular diagnosis of fragile $X$ syndrome in both males and females. This is achieved through a combination of specific amplification across the nonmethylated and methylated CGG repeats of the FMR1 gene, as well as amplification that is primed from within the methylated repeat itself.

- In addition to all normal and premutation males and females, all full mutation males and females were also accurately classified using this triple ms-PCR assay, regardless of the size of their expanded full mutation alleles. The assay produced concordant results on all 89 genomic DNA samples where the FMR1 (CGG) genotypes had previously been determined by Southern blot analysis or standard PCR methods.

- This method for fragile $X$ syndrome testing provides a suitable alternative to Southern blot analysis which is less time consuming and more amenable to the clinical testing environment.

repeat alleles), GM06890 (normal male with 30 repeat allele), GM06891 (premutation male with 117 CGG repeat allele), GM06892 (premutation male with 80-85 CGG repeat allele), and GM06852 (full mutation male with $>200$ repeat allele), which were obtained from the Coriell mutant cell repository in Camden, New Jersey, USA. Assay validation was done on 81 previously genotyped archival patient DNAs and normal DNAs from the DNA diagnostic laboratories of Johns Hopkins Hospital, KK Women's and Children's Hospital, and National University Hospital (Singapore). The study protocol was approved by the institutional review board of the National University Hospital.

\section{Sodium bisulphite treatment}

Methylated and non-methylated FMRI alleles were differentially modified in the presence of sodium bisulphite according to Clark et al (1994), ${ }^{11}$ but with modifications. Briefly, $\mathrm{NaOH}$ was added to $1 \mu \mathrm{g}$ DNA to a final concentration of $0.3 \mathrm{M}$ in a final volume of $5 \mu \mathrm{l}$. After a 15 minute incubation at $55^{\circ} \mathrm{C}, 75$ $\mu \mathrm{l}$ of fresh and prewarmed sodium bisulphite solution was added. The latter was prepared by dissolving $0.6 \mathrm{~g}$ of sodium bisulphite in $45 \mu \mathrm{l}$ of $10 \mathrm{M} \mathrm{NaOH}$ and $960 \mu \mathrm{l}$ of $\mathrm{dH}_{2} \mathrm{O}$. The deamination mixture was incubated at $55^{\circ} \mathrm{C}$ for five hours, then purified over a GFX ${ }^{\mathrm{TM}}$ column (Amersham Biosciences) and eluted in $50 \mu \mathrm{l}$ Tris-EDTA, pH 8. The purified deaminated DNA was then desulphonated by the addition of $50 \mu \mathrm{l}$ of

Abbreviations: $F M$, full mutation; $\mathrm{NL}$, normal mutation; $\mathrm{PM}$, premutation 


\begin{tabular}{|c|c|c|c|c|}
\hline Primer & $5^{\prime} \rightarrow 3^{\prime}$ sequence & $\begin{array}{l}\text { GenBank ID: } \\
\text { nucleotides }\end{array}$ & Concentration & Amplicon size ${ }^{*}$ \\
\hline \multicolumn{5}{|c|}{ Non-methylated allele PCR (non-Met-PCR) } \\
\hline Non-Met-F & $\begin{array}{l}\text { AAACACTCAACTCCAT } \\
\text { ПСААПTCACПТСА }\end{array}$ & L29074: & $0.2 \mu \mathrm{M}$ & $168 b p+3 n$ \\
\hline Non-Met-R & $\begin{array}{l}\text { GAGTIGTIITGAGA } \\
\text { GGTGGGTGTGGGT }\end{array}$ & $\begin{array}{l}\text { L29074: } \\
13935 \rightarrow 13906\end{array}$ & $0.2 \mu \mathrm{M}$ & \\
\hline \multicolumn{5}{|c|}{ Methylated allele PCR (Met-PCR) } \\
\hline Met- $F$ & $\begin{array}{l}\text { CCGCCTCTAAACGAA } \\
\text { CGACGAACCGACG }\end{array}$ & $\begin{array}{l}\text { L29074: } \\
13748 \rightarrow 13775\end{array}$ & $0.2 \mu \mathrm{M}$ & $108 b p+3 n$ \\
\hline Met-R & $\begin{array}{l}\text { GGTIGCGGGCGTIC } \\
\text { GAGGITIAGTCGTC }\end{array}$ & $\begin{array}{l}\text { L29074: } \\
13915 \rightarrow 13888\end{array}$ & $0.2 \mu \mathrm{M}$ & \\
\hline \multicolumn{5}{|c|}{ Methylated allele triplet primed PCR (mTP-PCR) } \\
\hline mTP-F & $\begin{array}{l}\text { GCCGCTACCAAAAAA } \\
\text { CGTACGACAACGCG }\end{array}$ & $\begin{array}{l}\text { L29074: } \\
13806 \rightarrow 13834\end{array}$ & $0.2 \mu \mathrm{M}$ & Not applicable \\
\hline mTP-R & $\begin{array}{l}\text { TACCGATACGCATCCC } \\
\text { AGTIGTCAGC(TCG) }\end{array}$ & Not applicable & $0.02 \mu M$ & \\
\hline Tail-R & $\begin{array}{l}\text { TACCGATACGCAT } \\
\text { CCCAGITGTCAGC }\end{array}$ & Not applicable & $0.2 \mu \mathrm{M}$ & \\
\hline
\end{tabular}

$0.2 \mathrm{M} \mathrm{NaOH}$ and incubation at $37^{\circ} \mathrm{C}$ for 15 minutes. After neutralisation with $50 \mu \mathrm{l}$ of $0.2 \mathrm{M}$ Tricine, the mixture was purified over a second $\mathrm{GFX}^{\mathrm{TM}}$ column, eluted in $50 \mu \mathrm{l}$ TrisEDTA, $\mathrm{pH} 8$, and stored at $-20^{\circ} \mathrm{C}$ until use. The sodium bisulphite treatment results in methylated and non-methylated FMRI alleles with distinct differences in nucleotide sequence (fig lA).

\section{Methylation specific PCR}

Three sets of primers were designed to amplify from the antisense strand of bisulphite modified DNA, one set targeting the non-methylated allele, and the other two sets targeting the methylated allele (table 1; fig 1B).

Specific amplification and sizing of the non-methylated FMRl repeat, designated as "non-Met-PCR", was accomplished with primers non-Met-F and non-Met-R. Amplification was carried out in a $50 \mu \mathrm{l}$ volume containing $0.2 \mu \mathrm{M}$ of each primer, $0.2 \mathrm{mM}$ dNTPs, $2.5 \mathrm{U}_{\text {HotStarTaq }}{ }^{\mathrm{TM}}$ DNA polymerase (Qiagen), $0.5 \times$ Q solution (Qiagen), $1 \times$ supplied PCR buffer (including $1.5 \mathrm{mM} \mathrm{MgCl}_{2}$ ), and $7 \mu \mathrm{l}$ (calculated at $\sim 100 \mathrm{ng}$ ) of bisulphite modified DNA. An initial denaturation at $95^{\circ} \mathrm{C}$ for 15 minutes was followed by 40 cycles of $98^{\circ} \mathrm{C}$ for one minute, $62^{\circ} \mathrm{C}$ for one minute, and $72^{\circ} \mathrm{C}$ for two minutes, followed by a final extension at $72^{\circ} \mathrm{C}$ for 10 minutes. This reaction is expected to detect all nonmethylated normal and premutation FMRI repeats (fig IC, upper panel).

Two different PCR reactions were carried out to detect the methylated allele. The first reaction, designated as "MetPCR", used primers Met-F and Met-R to amplify across the methylated FMRI repeat. Reaction conditions were similar to that for the non-Met-PCR, except that $1.5 \times \mathrm{Q}$ solution was used instead. This reaction is expected to determine all normal and premutation methylated allele sizes, as well as full mutation alleles up to 350 repeats (fig $1 \mathrm{C}$, middle panel).

The second methylated allele PCR reaction, designated "mTP-PCR", is an adaptation of the triplet primed PCR (TPPCR) strategy first described by Warner et al. ${ }^{12}$ In mTP-PCR, primers $\mathrm{mTP}-\mathrm{F}, \mathrm{mTP}-\mathrm{R}$, and Tail-R were used to amplify from within the methylated repeat (table 1 ; fig $1 \mathrm{~B}$ ). Reaction conditions were similar to that for Met-PCR, except that each reaction contained $0.2 \mu \mathrm{M}$ each of primers MTP-F and Tail-R, $0.02 \mu \mathrm{M}$ of primer mTP-R, and $14 \mu \mathrm{l}(\sim 200 \mathrm{ng})$ of the bisulphite modified DNA. In the presence of either a methylated premutation or full mutation allele, an mTPPCR product smear extending upwards beyond 300 base pairs (bp) is expected (fig lC, lower panel). This product is referred to as a pre/full mutation (PFM) smear. In normal female samples, smearing below $300 \mathrm{bp}$ (NL smear) is expected and represents product from the normal FMRI allele on an inactive $\mathrm{X}$ chromosome.

A $15 \mu \mathrm{l}$ aliquot of each non-Met-PCR, Met-PCR, and mTPPCR product was analysed by electrophoresis through a $1.5 \%$ agarose gel at $6 \mathrm{~V} / \mathrm{cm}$, stained with ethidium bromide for 30 minutes, and photographed over an ultraviolet transilluminator. The triple PCR assay will generate distinct banding and smear patterns depending on FMRI (CGG) $)_{n}$ genotype, and anticipated results for various genotypes are illustrated schematically in fig $1 C$. Throughout the results and discussion sections of this paper, NL, PM, and FM are used to indicate normal, premutation, and full mutation, respectively.

\section{RESULTS}

Initial assay optimisation studies were undertaken using DNA obtained from four male and four female cell lines from the Coriell cell repository. For each cell line, the products of the non-Met-PCR, Met-PCR, and MTP-PCR were easily visualised by ethidium bromide staining (fig $2 \mathrm{~A}$ ), and the FMRI (CGG) n genotype classifications obtained were consistent with their known fragile $X$ status (table 2). For example, in NL male 1 (cell line GM06890), the non-MetPCR reaction produced the expected single non-methylated NL allele, while the Met-PCR and MTP-PCR reactions were negative (fig 2A). The assay easily detected the nonmethylated PM alleles from both PM male l (GM06891) and male 2 (GM06892), as well as the methylated FM allele from the FM male 1 (GM06852). Using mTP-PCR analysis, a pre/full mutation (PFM) smear was observed only from FM male 1 (GM06852) among the male cell lines. A PFM smear is defined as a smear of DNA amplification product that extends upwards beyond $300 \mathrm{bp}$ and is characteristic of all full mutation alleles and most methylated premutation alleles.

The assay was also able to classify accurately the FMRI $(C G G)_{n}$ genotypes of the female cell lines. For example, NL female 1 (GM07175) showed an NL non-methylated allele 


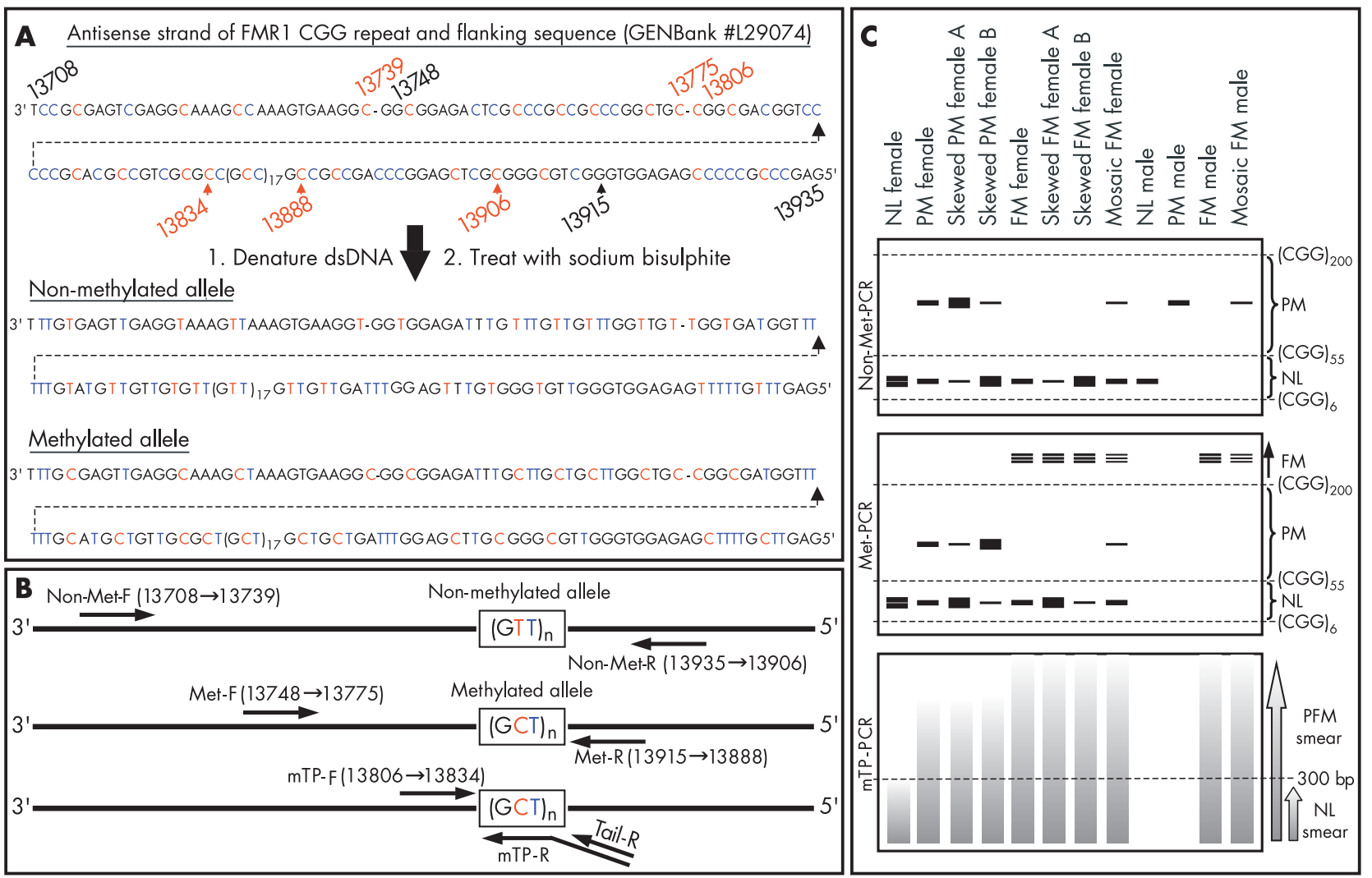

Figure 1 FMRI (CGG) methylation specific triple polymerase chain reaction (PCR) strategy. (A) Sodium bisulphite modification of non-methylated and methylated FMRI alleles. On non-methylated alleles, all dC residues of the CGG repeat and flanking sequences (red and blue) are converted to dU in the presence of sodium bisulphite, followed by replacement with dTs upon subsequent allele specific PCR. On methylated alleles, however, all dC residues of CPG dinucleotides (red coloured dCs) are methylated and remain unconverted. (B) Allele specific PCR amplification after sodium bisulphite modification. Primers were designed to amplify specifically from the bisulphite modified antisense strand of either the non-methylated or the methylated allele. Primers non-Met-F and non-Met-R will amplify across all non-methylated NL and PM alleles, while primers Met-F and Met-R will amplify across all methylated NL and PM alleles, as well as FM alleles of up to $\sim 350$ repeats. FM alleles that are too large to be amplified using met-F/R are detected by methylated allele triplet primed PCR (mTP-PCR) using primers mTP-F, mTP-R, and Tail-R. Five digit numbers in panels $A$ and $B$ indicate positions of nucleotides in GenBank entry No 29074. (C) Schematic illustration of ethidium bromide staining patterns after agarose gel electrophoresis of non-MetPCR (top panel), Met-PCR (middle panel), and mTP-PCR products (lower panel) from males and females of various FMR1 (CGG) n genotype classes. Skewed PM or FM female A, skewed X inactivation where an excess of cells have the NL allele on the inactive X chromosome; skewed PM or FM female $B$, skewed $\mathrm{X}$ inactivation where an excess of cells have the $\mathrm{NL}$ allele on the active $\mathrm{X}$ chromosome.

and an NL methylated allele after non-Met-PCR and MetPCR analyses, respectively, and a short smear not exceeding 300 bp (NL smear) was observed by mTP-PCR analysis. The NL and PM alleles in PM female 1 (GM06907) and female 2 (GM06896) were also easily detected using this triple PCR assay, as were the NL and FM alleles in FM female 1 (GM07537). Interestingly, the results also revealed evidence of non-random or skewed X inactivation in these cell lines, with the majority of cells carrying the NL allele on the active $\mathrm{X}$ and the PM and FM alleles on the inactive $\mathrm{X}$. We confirmed the skewed $X$ inactivation in these samples by Southern blot analysis (data not shown), and have quantified the degree of skewing in all four female cell lines using the HUMARA assay $^{13}{ }^{14}$ (table 2). As expected for the PM female and FM female cell lines, mTP-PCR analysis detected PFM smears in all three samples.

For each of the eight cell lines, the CGG repeats of the nonmethylated and methylated alleles were calculated from their respective non-Met-PCR and Met-PCR fragments according to the formula in table 1 . The calculated CGG repeats were concordant between the two PCRs and were in good agreement with the approximate CGG repeat sizes inferred from the Southern blot results (table 2). PCR products of FM alleles, however, could not be accurately sized beyond $1 \mathrm{~kb}$ on this gel system. Such alleles were labelled as having $>295$
CGG repeats, which is the literal conversion from a $\mathrm{l} \mathrm{kb}$ methylated fragment rounded off to the nearest five CGG repeats.

We further evaluated the assay on peripheral blood leucocyte DNAs of known FMRI (CGG)n genotype classification. These samples were selected to represent the widest spectrum of NL, PM, and FM FMRI genotypes that we have previously analysed. The triple PCR assay of non-Met-PCR, Met-PCR, and MTP-PCR reactions was able to classify the FMRI (CGG) nenotype of each male and female sample accurately (table 3). All non-methylated and methylated NL and PM alleles in males and females could be clearly detected (fig 2B). All samples carrying methylated PM or FM alleles generated a PFM smear by MTP-PCR, while NL males and PM males did not produce a smear, and NL females displayed only an NL smear.

This evaluation allowed us to delineate the upper limit of detection of FM alleles by Met-PCR analysis at $\sim 350$ repeats. Taking FM female 4 (FX0025) and FM male 3 (FX0012) as examples, the Met-PCR reaction failed to generate an amplification product from either sample (fig $2 \mathrm{~B}$, middle panel), both of whose FM alleles exceed 500 repeats as determined by Southern analysis (table 3 ). The MTP-PCR reaction, however, produced a PFM smear in both samples, thus ensuring that the FM alleles in both samples were not 

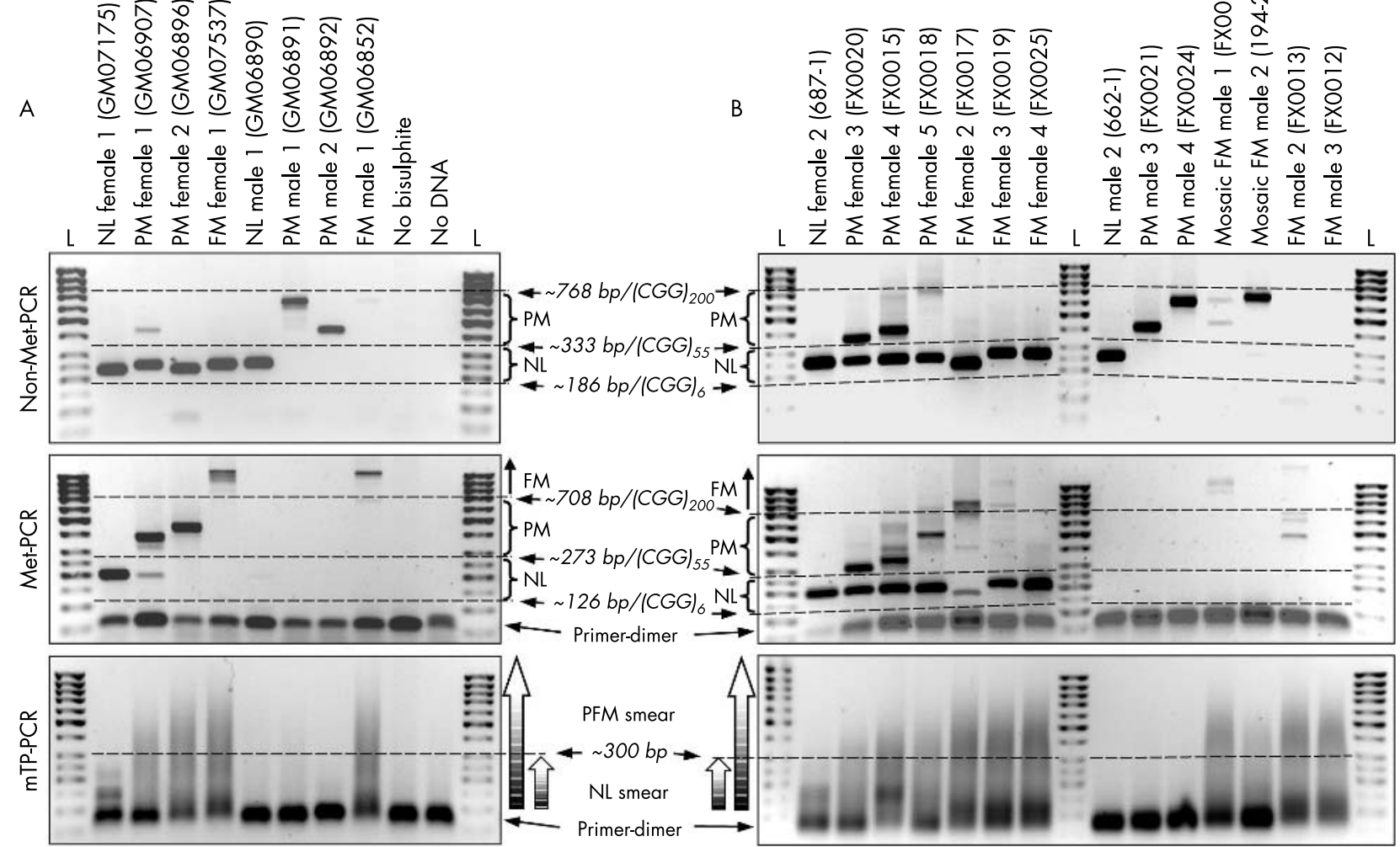

Figure 2 Agarose gel results of methylation specific triple polymerase chain reaction (PCR) of genomic DNA samples. (A) Optimisation on genomic DNA from female and male lymphoblastoid cell lines carrying NL, PM, and/or FM FMRI alleles. (B) Validation on leucocyte extracted female and male genomic DNA of known FMR1 genotype. Top panels, PCR across non-methylated CGG repeat (non-Met-PCR). Middle panels, PCR across methylated CGG repeat (Met-PCR). Bottom panels, triplet primed PCR of methylated allele (mTP-PCR). The "no bisulphite" result was derived from a female DNA sample that was not pretreated with sodium bisulphite. L, GeneRuler ${ }^{T M} 50$ bp DNA ladder (Fermentas).

missed. Although a PFM smear is also generated in the presence of a methylated PM allele, Met-PCR analysis did not detect any methylated PM allele in FM female 4 and FM male 3. Based on our observation that the non-Met-PCR and MetPCR reactions can reliably detect even the largest PM alleles among our pre-characterised samples, the negative Met-PCR results therefore indicate that the PFM smears of FM female 4 and FM male 3 must have been generated from FM alleles. The combined PCR results thus correctly classified both samples as carrying FM alleles.
To evaluate the specificity of the MTP-PCR reaction in producing a PFM smear only from methylated PM and FM alleles, we carried out mTP-PCR on genomic DNAs from additional NL, PM, and FM males and females. All "normal" samples were first confirmed to contain only an NL FMRI $(\mathrm{CGG})_{\mathrm{n}}$ allele (for the males), or two NL alleles (for the females) by direct amplification of the CGG repeat ${ }^{15}$ and fluorescence detection on an ABI 3100 genetic analyser. The mTP-PCR reaction did not produce any DNA smear in all NL male samples tested (fig 3A), whereas only the short NL

Table 2 Assay optimisation on female and male lymphoblastoid cell lines carrying NL, PM, and/or FM FMR1 (CGG) $n$ alleles

\begin{tabular}{|c|c|c|c|c|c|c|c|}
\hline Coriell ID/sex & $\begin{array}{l}\text { Southern result } \\
\text { (kb/CGG rpt*) }\end{array}$ & $\begin{array}{l}\text { Southern } \\
\text { classification }\end{array}$ & $\begin{array}{l}\text { Non-Met-PCR result } \\
\text { (bp/CGG rpt)† }\end{array}$ & $\begin{array}{l}\text { Met-PCR result } \\
\text { (bp/CGG rpt) } \dagger\end{array}$ & $\begin{array}{l}\text { mTP-PCR } \\
\text { result }\end{array}$ & $\begin{array}{l}\text { Triple ms-PCR } \\
\text { classification }\end{array}$ & $\begin{array}{l}\text { HUMARA } \\
\text { assay } \\
\text { (\% skewing) }\end{array}$ \\
\hline GM07175/F & 2.9 and $5.2 \mathrm{~kb} / 30 \mathrm{rpt}$ & NL female & $260 \mathrm{bp} / 30 \mathrm{rpt}$ & $200 \mathrm{bp} / 30 \mathrm{rpt}$ & NL smear & NL female & $\geqslant 85 \%$ \\
\hline GM06907/F & $\begin{array}{l}2.9 \text { and } 5.4 \mathrm{~kb} / 30 \\
\text { and } 100 \mathrm{rpt}\end{array}$ & $\begin{array}{l}\text { PM female } \\
\text { (skewed) } \neq\end{array}$ & $\begin{array}{l}260 \& 450 \mathrm{bp} / 30 \\
\& 95 \mathrm{rpt}\end{array}$ & $\begin{array}{l}200 \& 390 \mathrm{bp} / 30 \\
\& 95 \mathrm{rpt}\end{array}$ & PFM smear & $\begin{array}{l}\text { PM female } \\
\text { (skewed) } \neq\end{array}$ & $\geqslant 95 \%$ \\
\hline GM06896/F & $\begin{array}{l}2.9 \text { and } 5.4 \mathrm{~kb} / 30 \\
\text { and } 100 \mathrm{rpt}\end{array}$ & $\begin{array}{l}\text { PM female } \\
\text { (skewed) } \ddagger\end{array}$ & $260 \mathrm{bp} / 30 \mathrm{rpt}$ & $470 \mathrm{bp} / 120 \mathrm{rpt}$ & PFM smear & $\begin{array}{l}\text { PM female } \\
\text { (skewed) } \ddagger\end{array}$ & $\geqslant 99 \%$ \\
\hline GM07537/F & $\begin{array}{l}2.9 \text { and } 6.3 \mathrm{~kb} / 30 \\
\text { and } 400 \mathrm{rpt}\end{array}$ & $\begin{array}{l}\text { FM female } \\
\text { (skewed) } \ddagger\end{array}$ & $270 \mathrm{bp} / 35 \mathrm{rpt}$ & $>1000 \mathrm{bp} />295 \mathrm{rpt}$ & PFM smear & $\begin{array}{l}\text { FM female } \\
\text { (skewed) } \neq\end{array}$ & $\geqslant 99 \%$ \\
\hline GM06890/M & $2.9 \mathrm{~kb} / 30 \mathrm{rpt}$ & NL male & $270 \mathrm{bp} / 35 \mathrm{rpt}$ & No PCR pdt & No smear & NL male & NA \\
\hline GM06891/M & $3.3 \mathrm{~kb} / 150 \mathrm{rpt}$ & PM male & $640 \mathrm{bp} / 155 \mathrm{rpt}$ & No PCR pdt & No smear & PM male & NA \\
\hline GM06892/M & $3.1 \mathrm{~kb} / 100 \mathrm{rpt}$ & PM male & $410 \mathrm{bp} / 80 \mathrm{rpt}$ & No PCR pdt & No smear & PM male & NA \\
\hline GM06852/M & $6.3 \mathrm{~kb} / 400 \mathrm{rpt}$ & FM male & $640 \mathrm{bp} / 155 \mathrm{rpt}$ & $>1000 \mathrm{bp} />295 \mathrm{rpt}$ & PFM smear & Mosaic FM male & NA \\
\hline
\end{tabular}

*Repeat sizes are based on EcoRl/Nrul double digests hybridised with probe StB 12.3 , where a $2.9 \mathrm{~kb}$ non-methylated or a $5.2 \mathrm{~kb}$ methylated fragment indicates a 30 repeat normal allele. Larger fragments are rounded off to the nearest 50 repeats.

tRounded off to the nearest $10 \mathrm{bp}$ and five CGG repeats.

$\ddagger$ Majority of cells carry the NL FMRI allele on the active $X$ and the PM or FM allele on the inactive X.

$F$, female; $M$, male; NA, not applicable; pdt, product; rpt, repeats. 
Table 3 Assay validation on peripheral blood DNAs of NL, PM, and/or FM females and males

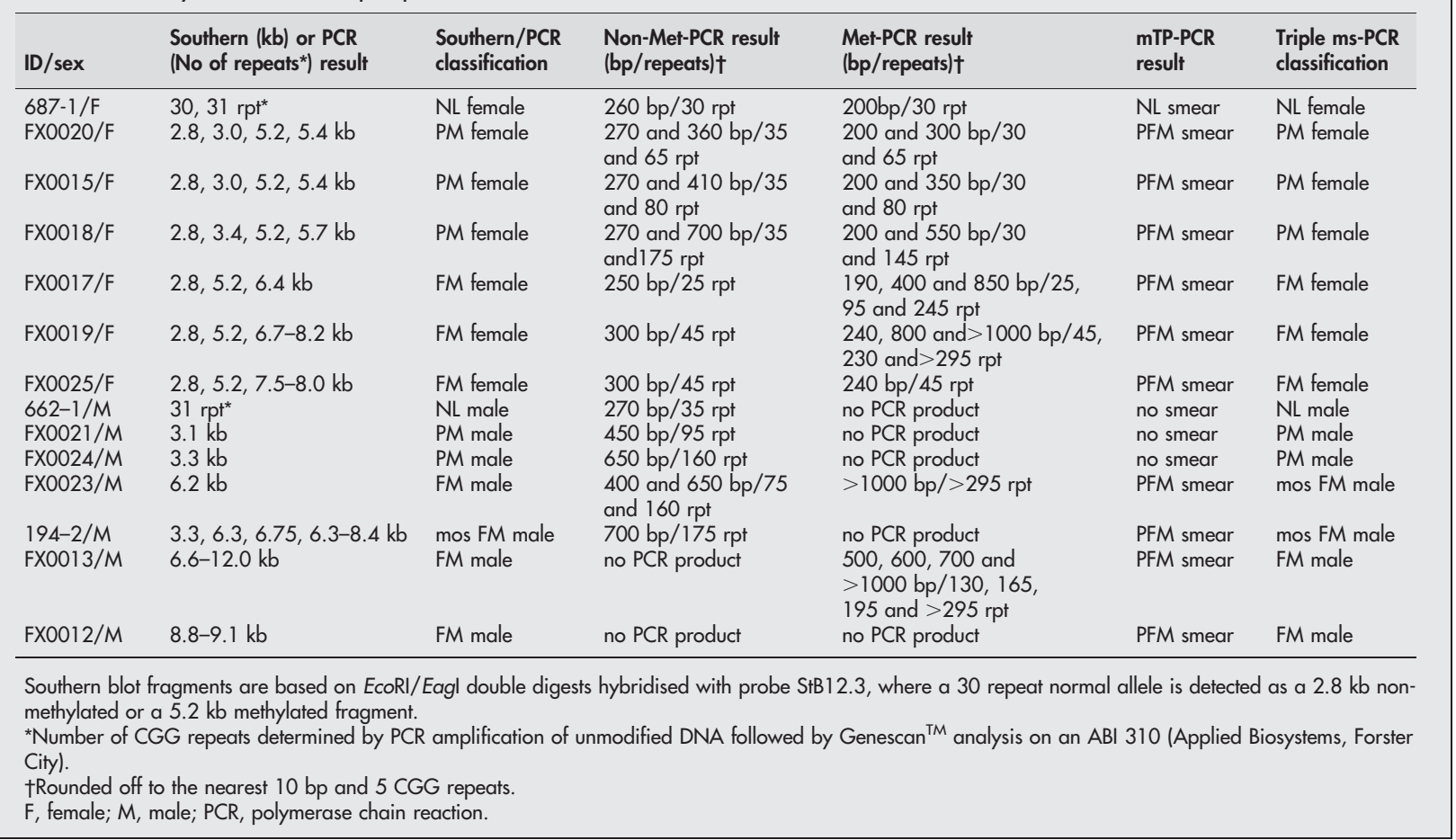

smear was evident in all NL female samples (fig 3B). In contrast, the PFM smears generated from all FM males (fig 3C) and all PM and FM females (fig 3D) were clearly more extensive. Although it is conceivable that the NL smear from a large NL allele (for example, 50 CGGs) would be quite similar to a PFM smear from a small PM allele (say 60 CGGs), the non-Met-PCR and/or Met-PCR results will distinguish between most NL and PM alleles by size, confirmed by sequencing or pedigree analysis if necessary. For those samples where the allele sizes fall within the 50-60 CGGs range, further pedigree or sequencing analysis of the CGG repeat structure is necessary for proper mutation classification.

An algorithm for the classification of the various female and male FMRI (CGG) nenotypes is shown in fig 4, and is intended to simplify interpretation of the agarose gel results obtained from this methylation specific triple PCR assay.

\section{DISCUSSION}

More than a decade after the identification of a trinucleotide repeat expansion in the FMRI gene as the predominant cause of fragile X mental retardation syndrome, molecular diagnosis of this disorder continues to rely mainly on a combination of PCR and Southern blot analyses. Southern blot analysis is very robust in detecting FM expansions in both males and females. However, it is highly labour intensive and time consuming. Additionally, Southern blots are not ideal for detecting PM alleles at the low end of the size range. PCR amplification across the CGG repeat enables precise sizing, but only of NL and small PM alleles. Larger PM and FM alleles cannot be detected reliably using conventional PCR. Furthermore, PCR does not provide information on the methylation status of the alleles.

More recently, several assays based on ms-PCR have been developed in attempts to address the deficiencies of PCR based methods. ${ }^{9}{ }^{10}{ }^{16}$ Ms-PCR methods rely on the differential modification of methylated and non-methylated genomic DNA by sodium bisulphite, allowing subsequent specific amplification and detection of methylated and non-methylated alleles. ${ }^{11}$ This procedure converts the non-methylated FMRI trinucleotide repeat from 100\% G:C base pairing (5'CCG $-3^{\prime}$ on the antisense strand) to one with $33 \% \mathrm{G}: \mathrm{C}$ base pairing (5'-TTG-3' repeat), while the methylated repeat now has $\sim 67 \%$ G:C base pairing ( $5^{\prime}-\mathrm{TCG}-3^{\prime}$ repeat) (fig 1 ). Thus this conversion not only allows non-methylated alleles to be discriminated from methylated alleles, but also reduces the difficulty of amplifying across the repeats. Even so, larger PM and FM alleles remain refractory to amplification and detection, and are especially difficult to detect in females owing to preferential amplification of their NL alleles.

Weinhausel and Haas (2001) developed a dual PCR methylation specific PCR assay for detection of fragile $\mathrm{X}$ syndrome in both males and females. ${ }^{10} F M R I$ genotypes were identified on the basis of several parameters, including a duplex-PCR of the FMRI and XIST gene promoters coupled with a duplex PCR across the non-methylated and methylated CGG repeats, followed by densitometric ratio analysis of FMRI promoter methylation status normalised against that of the XIST promoter. These investigators reported that virtually all categories of FMRI genotypes could be detected, although noting that very large PM alleles in female carriers could be missed, thus resulting in occasional difficulties in distinguishing a PM female from an FM female.

Our assay differs from the method of Weinhausel and Haas $^{10}$ in two main respects. First, our assay involves three single PCR amplifications instead of two duplex PCR reactions. We chose not to duplex the non-Met-PCR with the Met-PCR after initial trials indicated a reduced detection sensitivity, especially of the large PM and the FM alleles (data not shown). Separate agarose gel analysis of the nonMet-PCR and Met-PCR reactions allows easy identification of non-methylated and methylated alleles and approximate sizing of NL, PM, and FM bands. With a duplex PCR format, agarose gel analysis of the combined non-methylated and methylated PCR products is less straightforward, especially for certain NL and PM female genotypes, owing to the 

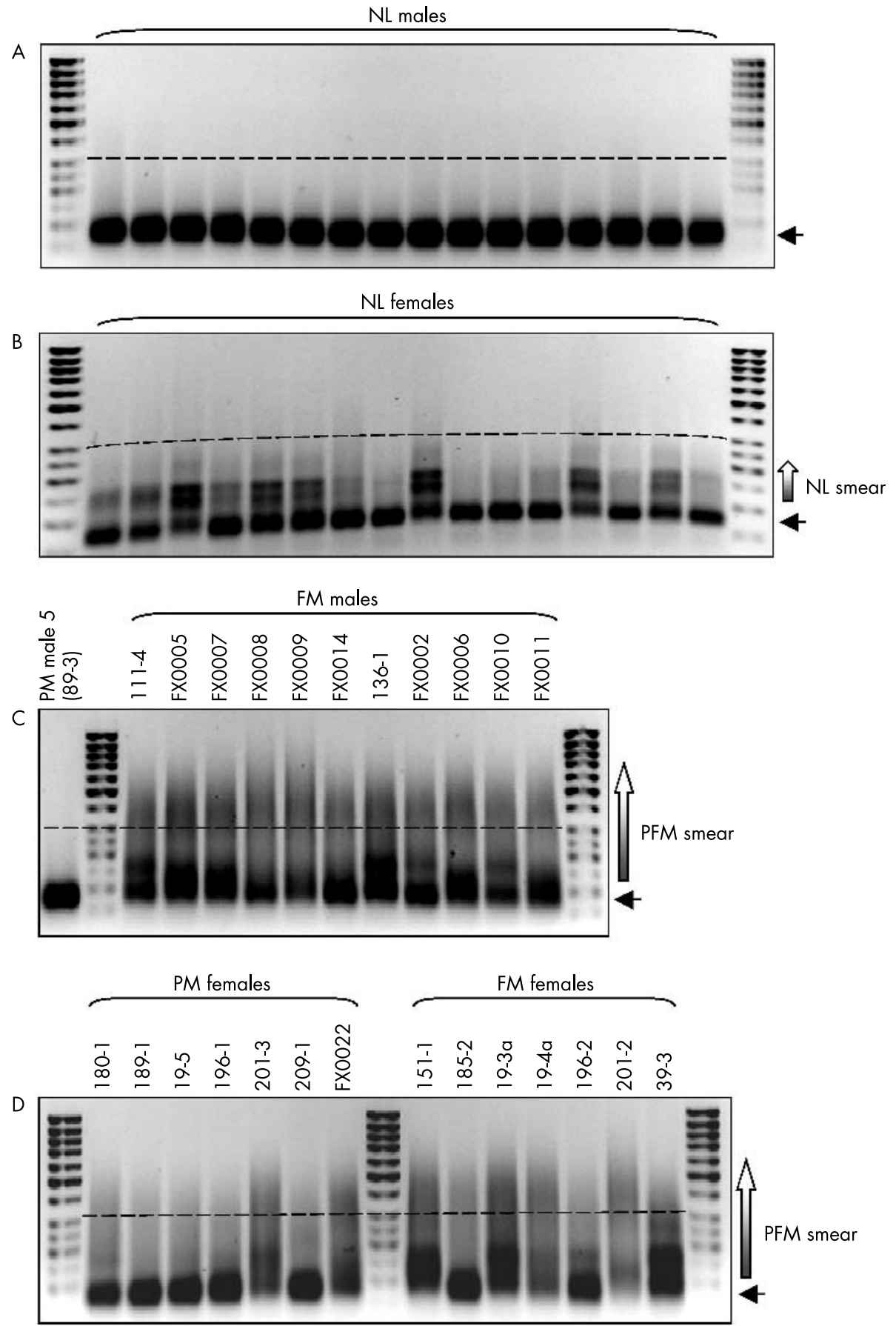

Figure 3 Specificity of a methylated allele, triplet primed, polymerase chain reaction (mTP-PCR) assay for methylated PM and FM FMR1 alleles. Additional male and female genomic DNAs of known FMR 7 (CGG) $n$ genotype were analysed by mTP-PCR. (A) Absence of a product smear from NL males. (B) Presence of a short NL smear from NL females. (C) Absence of a product smear from PM male and presence of a PFM smear from FM males. (D) Presence of a PFM smear from both PM females and FM females. Dashed horizontal lines delineate $\sim 300$ bp mark, and horizontal arrows indicate positions of primer-dimers. bp, base pairs.

possibility of overlapping non-methylated and methylated fragment sizes or co-migrating non-methylated and methylated fragments of the same size.

Second, our assay does not rely on densitometry and ratio analysis of non-methylated versus methylated promoter PCR fragments to detect FM alleles. We instead used a protocol modified from the triplet primed PCR (TP-PCR) method of Warner et al, ${ }^{12}$ in order to detect affected males and females with very large FM alleles that could not be amplified successfully using Met-PCR. Our mTP-PCR reaction reliably and specifically detects all PM and FM alleles. Although the mTP-PCR PFM smear generated from a PM female is indistinguishable from that of an FM female, the two genotype classes can be distinguished on the basis of their non-Met-PCR and Met-PCR results. A PM female will display a band in the PM size range in both the non-Met-PCR and Met-PCR gels, whereas an FM female with a large expansion of $>350$ CGG repeats will not display a band in either the PM or the FM size ranges using either non-Met-PCR or Met-PCR; and an FM female with a smaller expansion of $\leqslant 350$ will 

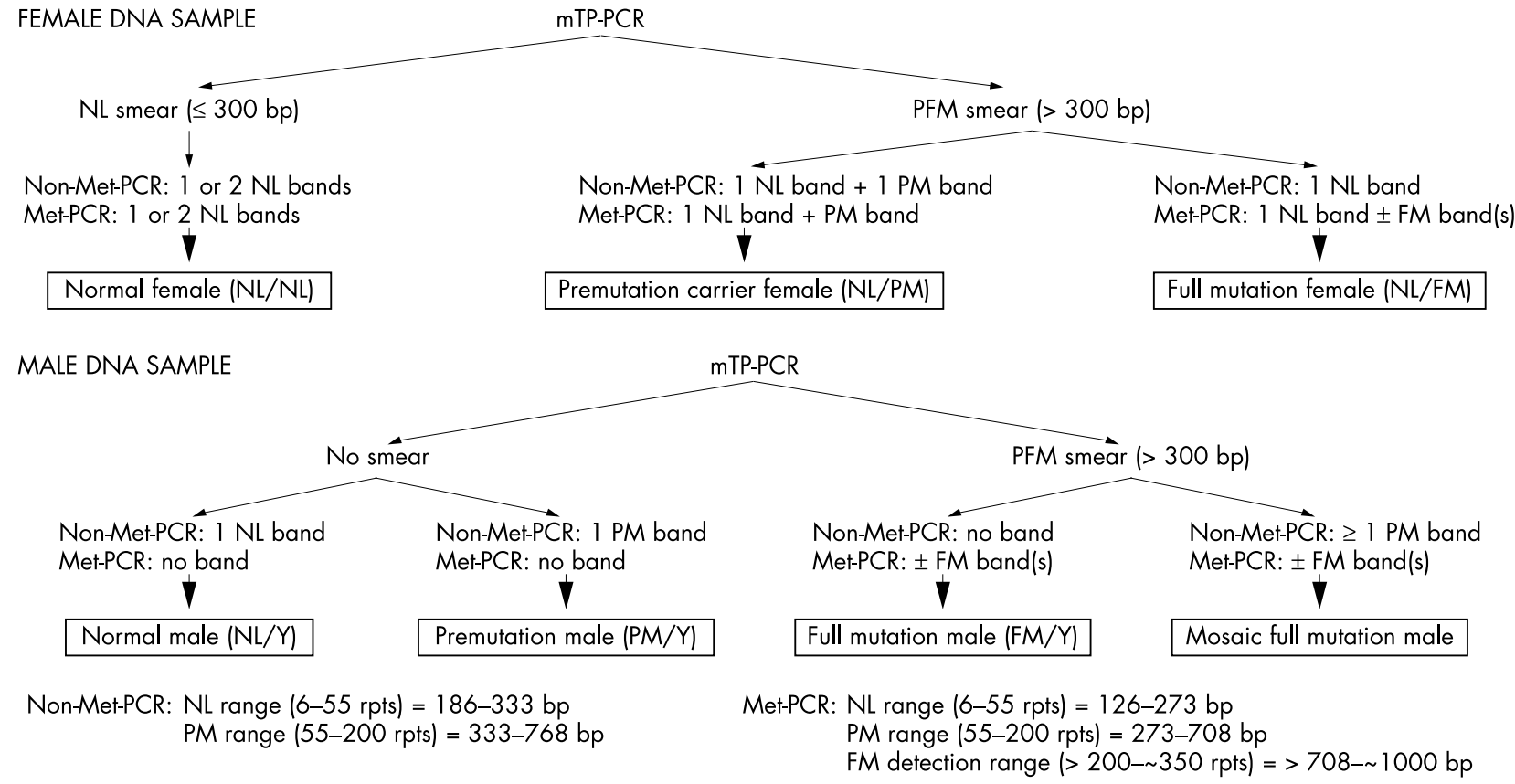

Figure 4 Algorithm for interpretation of triple methylation specific polymerase chain reaction assay results. Met, methylated; mTP-PCR, methylated allele, triplet primed, polymerase chain reaction; non-Met, non-methylated; PFM, pre/full mutation.

display an FM size band in the Met-PCR gel only. The presence of a methylated smear extending beyond $300 \mathrm{bp}$ is thus diagnostic of all FM males, PM females, and FM females. The PFM smear is not observed in NL males or PM males, while NL females have their own characteristic ethidium bromide staining patterns (fig 3 ).

In the majority of samples tested, the sizes of the nonmethylated and methylated alleles, determined from the non-Met-PCR and Met-PCR analyses, respectively, were concordant and were in good agreement with the approximate CGG repeat sizes inferred from the previous Southern blot or direct PCR results (tables 2 and 3). In PM female 5 (FX0018), however, the non-methylated and methylated PM amplicons migrated as apparently different sizes (table 3 ). We postulate that the observed CGG repeat discrepancy between the non-Met-PCR and Met-PCR products in PM female 5 most probably reflects the combined effect of her very large PM allele (>140 CGGs) coupled with the difference in nucleotide sequence composition between the modified non-methylated and methylated alleles. These two factors result either in anomalous retarded migration of the bisulphite modified non-methylated PM amplicon compared with its methylated counterpart, or conversely in anomalous accelerated migration of the bisulphite modified methylated PM amplicon compared with its non-methylated counterpart. Whether the methylated or non-methylated PM amplicon represents the true CGG repeat length has not been determined, owing to the difficulty in sequencing across such long CGG repeat stretches. The discordant sizes of these samples should not, however, lead to misdiagnosis or misclassification of their FMRI genotypes.

It is possible that this assay may misclassify a female mosaic for PM and FM alleles as a constitutive PM female when only the PM allele but not the FM allele is detected by Met-PCR. Such situations may, however, be rare as many mosaic females carry multiple FM alleles including some of less that 350 CGG repeats. If this is the case, the Met-PCR reaction may be able to amplify and detect the smaller FM alleles.
It should be noted that even the gold standard Southern blot analysis is not completely error-proof. For example, some FM affected females harbour highly somatically unstable FM alleles, which sometimes makes them difficult to detect. Detection of such alleles by Southern analysis is obvious only under optimal probe labelling, hybridisation, and wash conditions that maximise signal and minimise background noise. Thus the triple ms-PCR method for fragile $X$ testing demonstrated here provides a suitable alternative to Southern blot analysis which is less time consuming and more amenable to the clinical testing environment.

\section{ACKNOWLEDGEMENTS}

This work was supported by grant NMRC/0425/2000 from the National Medical Research Council, Singapore to SSC.

Electronic database information: URL for fragile $\mathrm{X}$ syndrome [OMIM No 309550]: http://www.ncbi.nlm.nih.gov/Omim

\section{Authors' affiliations}

Y Zhou, S S Chong, Department of Paediatrics, National University of Singapore, Singapore

H-Y Law, C-S Yoon, I S L Ng, Department of Paediatric Medicine, KK Women's and Children's Hospital, Singapore

C D Boehm, G R Cutting, Department of Pediatrics, The Johns Hopkins University School of Medicine, Baltimore, Maryland, USA

Competing interests: none declared

Correspondence to: Dr Samuel S Chong, Department of Paediatrics and Children's Medical Institute, National University of Singapore and Hospital, Level 4, NUH, 5 Lower Kent Ridge Road, Singapore 119074; paecs@nus.edu.sg

\section{REFERENCES}

1 Jin $\mathbf{P}$, Warren ST. Understanding the molecular basis of fragile $X$ syndrome. Hum Mol Genet 2000:9:901-8.

2 Fu YH, Kuhl DP, Pizzuti A, Pieretti M, Sutcliffe JS, Richards S, Verkerk AJ, Holden JJ, Fenwick RG, Warren ST, Oostra BA, Nelson DL, Caskey CT. Variation of the CGG repeat at the fragile $X$ site results in genetic instability: resolution of the Sherman paradox. Cell 1991;67:1047-58. 
3 Kremer EJ, Pritchard M, Lynch M, Yu S, Holman K, Baker E, Warren ST, Schlessinger D, Sutherland GR, Richards RI. Mapping of DNA instability at the fragile $X$ to a trinucleotide repeat sequence $p(C C G) n$. Science 1991;252:1711-14

4 Verkerk AJ, Pieretti M, Sutcliffe JS, Fu YH, Kuhl DP, Pizzuti A, Reiner O Richards S, Victoria MF, Zhang FP, Enssen BE, van Ommen GJB, Blonden LAJ, Riggins GJ, Kunst CB, Galjaard H, Caskey CT, Nelson DL, Oostra BA, Warren ST. Identification of a gene (FMR-1) containing a CGG repeat coincident with a breakpoint cluster region exhibiting length variation in fragile X syndrome. Cell 1991;65:905-14.

5 Heitz D, Devys D, Imbert G, Kretz C, Mandel JL. Inheritance of the fragile X syndrome: size of the fragile $X$ premutation is a major determinant of the transition to full mutation. J Med Genet 1992;29:794-801.

6 Turner AM, Robinson H, Wake S, Laing SJ, Leigh D, Turner G. Counselling risk figures for fragile $X$ carrier females of varying band sizes for use in predicting the likelihood of retardation in their offspring. Am J Med Genet 1994;51:458-62.

7 Dewald GW, Buckley DD, Spurbeck JL, Jalal SM. Cytogenetic guidelines for fragile X studies tested in routine practice. Am J Med Genet 1992:44:816-21.

8 Pai JT, Tsai SF, Horng CJ, Chiu PC, Cheng MY, Hsiao KJ, Wuu KD. Absence of FMR-1 gene expression can be detected with RNA extracted from dried blood specimens. Hum Genet 1994;93:488-93.
9 Oostra BA, Willemsen R. Diagnostic tests for fragile X syndrome. Expert Rev Mol Diagn 2001;1:226-32.

10 Weinhausel A, Haas OA. Evaluation of the fragile X (FRAXA) syndrome with methylation-sensitive PCR. Hum Genet 2001;108:450-8.

11 Clark SJ, Harrison J, Paul CL, Frommer M. High sensitivity mapping of methylated cytosines. Nucleic Acids Res 1994;22:2990-7.

12 Warner JP, Barron LH, Goudie D, Kelly K, Dow D, Fitzpatrick DR, Brock DJ. A general method for the detection of large CAG repeat expansions by fluorescent PCR. J Med Genet 1996;33:1022-6.

13 Allen RC, Zoghbi HY, Moseley AB, Rosenblatt HM, Belmont JW. Methylation of $H$ pal $I$ and $H$ hal sites near the polymorphic CAG repeat in the human androgen-receptor gene correlates with X chromosome inactivation. Am J Hum Genet 1992;51:1229-39.

14 Plenge RM, Hendrich BD, Schwartz C, Arena JF, Naumova A, Sapienza C, Winter RM, Willard HF. A promoter mutation in the XIST gene in two unrelated families with skewed X-chromosome inactivation. Nat Genet 1997; 17:353-6.

15 Chong SS, Eichler EE, Nelson DL, Hughes MR. Robust amplification and ethidium-visible detection of the fragile $X$ syndrome CGG repeat using Pfu polymerase. Am J Med Genet 1994;51:522-6.

16 Panagopoulos I, Lassen C, Kristoffersson U, Aman A. A methylation PCR approach for detection of fragile X syndrome. Hum Mutat 1999;14:71-9. 